\title{
Evaluation of Risk-Based Internal Audit Plan Implementation in the Era of Technology Disruption: Case Study at University X
}

\author{
Ruth Artia Heldifanny \\ Department of Accounting \\ Faculty of Economics and Business, Universitas Indonesia \\ Depok, Indonesia \\ ruthartia@gmail.com
}

\author{
Robert Porhas Tobing \\ Department of Accounting \\ Faculty of Economics and Business, Universitas Indonesia \\ Depok, Indonesia \\ robert.tobing16@gmail.com
}

\begin{abstract}
This study aims to analyze the implementation of a risk-based internal audit plan at University $X$. The real challenge for an internal audit in every organization including higher education is to recognize the disruption that may arise and to provide insights to the board. Because every organization has its own risk profile, a one-size-fits-all internal audit plan might not suit the organization's needs. This paper discusses how disruptions in higher education lead to internal audits, disrupting their ways of implementing risk-based internal audits.
\end{abstract}

Keywords-internal audit, risk-based internal audit, risk identification and assessment process, higher education disruption, higher education risk, internal audit disruption, catalyst of change

\section{INTRODUCTION}

Changes in the environment and every order of human life today are strongly influenced by advancements in information technology. Today, the world is entering industrial revolution 4.0 , which is much different from the previous era. Industrial revolution 4.0 is also called the digital revolution era or technology disruption era. This era has already changed the development of technology and the social point of view. Peter Diamandis stated that, in 2025, society will move toward a world of true abundance as changes are accelerated in many different aspects of human life [1].

We can expect that, in the near future, we will be able to purchase a computer with the ability to process data equivalently to the human mind. In addition, with a trillion sensors collecting information everywhere (through big data and algorithm), we will be able to know anything that we need to know anytime and anywhere, and query such information for answers. Furthermore, approximately eight billion associated people will be online with 1-Mbps connections that will give them access to all of the data on Google, cloud 3D printing, Amazon Web administration, artificial intelligence, crowdfunding, and crowdsourcing - the sky is the limit [1].

All aspects of industry, including higher education, will be affected by the technological disruption era. However, the higher education sector seems not ready for this disruption because this sector's systems and frameworks have not changed significantly relative to previous centuries. We could state that the system used is still from the medieval times. The present higher education system has an inflexible structure and is already out of date when compared with the potential offered by newer innovations or technology advancements. The current system does not prepare students to meet the needs of the present century.

Based on innovative improvements and technology developments and through the crystallization of the education system and framework, we require significant changes to teaching and learning processes. In the future, universities will not have classrooms or lessons but, instead, a great deal of innovation and technology; therefore, they are expected to focus more on a transdisciplinary interface among innovation and mankind and, in this way, more strongly attenuate personalization. The situation is beginning to change, but only moderately. The unavoidable issue today is how to plan individualized educational modules for every student, considering that students can connect past the walls of their classrooms to different students, different instructors, and authors, researchers, and specialists to enhanced their knowledge and skills. A solution can be considered to utilize innovation and technology to encourage every student and higher education institutions to develop their own methods for learning over a few fields to permit holistic higher education [1].

Therefore, higher education needs to see the importance of facing the risk emerging from an era of technological disruption to not only win in the current competitive environment but also to evolve. Similar to every other organization, higher education always attempts to not only survive but also grow larger in scale, scope, and prestige. Therefore, the position of higher education in the era of technology disruption will determine the continuity of its operations.

For internal auditors to add value to the organization, internal audit processes should be effective and efficient. At University X, the Internal Control Unit (Satuan Pengawas Internal-SPI) and the Risk Management Unit (Satuan Manajemen Risiko-SMR) are the parties that play a role in risk management and should become the change catalysts for University X. Together with SMR, SPI has implemented a risk-based internal audit in the risk management of University $\mathrm{X}$. However, a gap certainly exists in the internal audit plan by SPI University X, which requires an evaluation to ensure that audit activities are more effective and efficient and provide value added to the organization. Therefore, an internal audit should provide a proper response in this rapidly changing 
environment by developing an effective management system. An internal audit should evaluate an organization's strategy and operating environment to develop a holistic view of the risk facing the business to allow for identifying, evaluating, and prioritizing the correct risk [2].

\section{LITERATURE REVIEW AND HYPOTHESIS DEVELOPMENT}

\section{A. Disruption of Technology}

"Disruptive technologies" and "disruptive innovations" were first introduced by Christensen and Bower (as cited in Schuelke-Leech) [3], who described disruptive technologies as those that cause an upheaval in the existing market and dominate firms by being less expensive, simpler, and more convenient than the dominant technologies [3]. Disruptive innovation is simply defined as a period during which numerous emerging innovations were developed that were unrecognized by established organizations because they interfered with the activities of the old system order or even destroyed the old system [4].

\section{B. Disruption in Higher Education}

For past centuries, traditional universities have focused their efforts on become bigger and better in scale and scope by following standards set by other great universities, such as Harvard, Oxford, or other world-class universities (WCUs). This strategy has proven successfully in the past, resulting in the emergence of many private and public universities that have strong competitiveness, as do WCUs. Because higher education institutions are familiar through their famous names, they do not move quickly. Higher education has avoided a competitive disruptive environment and innovation because of its power and prestige in the marketplace. In the absence of comparable measures of what universities produce for their students, these well-respected institutions already have a natural advantage [5]. Technology advances have transformed academic research and publishing and have been incorporated in familiar teaching methods. However, universities have not significantly changed their curricula or how they teach [6].

In their book, Christensen and Eyring [5] stressed that universities need to rethink the entire model of higher education through disruptive technology and offer new ways related to curriculum, faculty, enrollment, student retention, graduation rates, campus facility utilization, and other related issues. Currently, we are in the era of VUCA, which stands for volatility, uncertainty, complexity, and ambiguity. Students today have more information than their lecturers and gain this knowledge from the Internet and other resources - in other words, they utilized their personal learning.

Pincus et al. [6] referred to forces rather than disruption. Two major forces that can change higher education are financial forces and technology forces. Financial forces are driven by changes in economic prosperity and demographic favorability. Meanwhile, technology has transformed teaching and learning processes and how research is conducted to be more practical and efficient. Digital technologies provide opportunities to prepare students for 21 st century careers and to create new financial models for higher education [7]. Therefore, in the face of pressing financial and technology forces for change, every higher education institution needs to move from long-successful financial and curriculum models to new models that fit with the conditions of the 21 st century [6].

One example of higher education disruption in the teaching and learning process is the growth of distance learning through online forms. Online education has been suggested as a "revolutionary" solution to diverse educational problems of inequality. Adopting online forms for educational delivery has been anticipated to enhance the "accessibility" of university education, and that expectation has tended to underpin further suggestions of an expansionary nature: that adopting online education throughout the higher education (HE) sector is imperative [8]. This argument was also noted on the state of e-learning in Canada: [ICTs] bring advantages to the learning process that are not readily available in other ways. The most prominent of these advantages are better access to learning; better allocation of teaching resources; shared learning content; deeper learning; and a social component to learning. The learning potential of technology and the Internet is evident and can provide one solution to the growing demand for post-secondary education, skills, and training [9].

Regarding disruptions in internal audit practices, [10 - 16] internal conformation to the Institute of Internal Auditor's (IIA's) definition of independent and objective assessment means providing consulting activities designed to add value and enhance the operational activities of the organizational changes in the business environment, technological advances, and developments in regulatory and regulatory frameworks that led to major changes in audit approaches adopted by internal auditors [17 - 18]. The basis of a modern internal audit is a risk assessment, whereby internal auditors should be able to manage the risks arising from changes at each level, especially changes directly related to risks [19] that can threaten the organization [20]. To understand and properly assess risks, internal auditors must gain a deep understanding of the operations performed by the organization through the data collection.

The role of internal auditors has changed from being clerical officers to being strategic partners for top management of the organization. The role of the internal auditor is no longer merely to be a watchdog but also to be a consultant and catalyst for change [21]. This transformation is supported by a survey conducted by the Common Body of Knowledge of 433 stakeholders in North America that showed that as many as $85 \%$ wanted internal auditors to identify potential risk areas; $78 \%$ wanted the role of internal auditors to be to oversee the organization's risk management; and $78 \%$ wanted internal auditors to identify an effective risk management framework for the organization [22].

IIA [25] defined a risk-based internal audit as a methodology that links audit activities with the overall organizational risk management framework. A risk-based internal audit (RBIA) enables internal auditors to provide an assessment to the board that the risk management process has effectively managed the organization's risk in accordance with its risk appetite. RBIA procedures emphasize the importance of identifying inherent risks to strategic plans and testing and reporting the adequacy and effectiveness of risk mitigation procedures [23 - 24]. IIA [25] stated that the benefits of RBIAs are as follows: 
1) By implementing a RBIA, management identifies, assesses, and responds to risks that are higher or lower than the risk appetite of the organization.

2) Responding to the risks identified by the internal auditor is effective and not excessive.

3) A RBIA allows the auditor to provide recovery measures on residual risk that may not fall within the risk appetite.

4) The effectiveness of risk management processes can be monitored by management.

5) Risks, responses related to risks, and actions taken are to be classified and reported.

The IIA [25] stated that the internal audit role in risk management is to accompany management, audit committees, and other supervisory roles in carrying out risk management responsibilities by assessing, evaluating, reporting, and recommending improvements to risk management processes. For the internal audit to provide appropriate assurance of the organizational risk management process, it must be independent of the activities to which it is reviewing $[25,13]$ to avoid risks such as judgments on self assessment (selfreview), social pressure, and familiarity [26-28]. Therefore, in its position paper entitled, The Role of Internal Auditing in Enterprise Risk Management [29], the IIA outlines three categories of internal auditors' roles in enterprise risk management: recommended roles, legitimate internal audit roles with safeguards, and roles that an internal audit should not undertake.

However, the question is how capable is the current RBIA approach of helping the organization respond to the risks that emerge from a disruptive environment?

According to IIA [30], organization can sometimes sense that the disruption is about to come, but they do not prepare for the impact it can caused. Being surprised is the principal challenge of disruption today, and the key is how quickly and easily we can emerge. Organizations have two choices: be ready and always prepared or do nothing and be surprised.

The real issue for internal audits to consider is how to recognize disruptions in their true form. It is important for internal audit to identify what kind of disruption that is coming, and providing valuable insight to leaders and managements of how they can take advantage of that disruption [30]. Often, an organization can see a disruption from miles away. To add value, the internal auditor must be able to interpret the significance of a coming disruption to the leaders or managers in organization, which enable them to make better judgment and appropriate response [30].

What we know from every business disruption is that no single organization can stop or slow down the wave of disruption at any kind. At this point, every internal auditor should be able to see every opportunity and risk that generated by a disruptive force, also provide leaders and managers with a proper understanding in determining the relevant strategies for organization to take in order identify and manage their risks [30]. What type of operational, financial, compliance, or reputational risks can a disruption bring to an organization? This question must be asked by every internal auditor to perform a more thorough form of risk assessment for the organization.
A survey conducted by PricewaterhouseCooper's (PwC) State of Internal Audit Survey in 2017 among board members and organization leaders express some concern towards the internal audit function in managing risk throughout the organization [31]. The data shows $38 \%$ of them claimed that their internal audit facing real challenge to play their role as the catalyst of change due to inadequacy of resource and expertise to manage disruptions. The solution to overcome this problem is to embrace an innovative approach to carrying out the audit by working smarter using data analysis or software tools that enable an analysis of the whole set of data instead of taking some samples [16]. Through the proper use of smarter technology and better analytics, the internal audit in every organization can predict the future disruptions.

According to Charlie Wright, director of Enterprise Risk Solution in Oklahoma, as cited in IIA's Global Perspective and Insight [30], there are several practical ways that can be followed by internal auditor to manage risks from technological disruption.

1) Focus on Assurance. The main function of internal audit is to do the risk management process. Therefore, intrenal audit should maximizing their roles in identify and assess risks, and evaluate the effectiveness of controls designed, to ensure that the business process and governance have conducted in the most effective and efficient way to achieve organization's objective, especially in the rapid growth of technology [30].

2) Engage with Stakeholders and Subject Matter Experts. Regarding some concerns about internal audit performance expressed by the board and managers [31], internal audit should consider to work closer with every stakeholders or experts, to provide their needs and meet their expectations [30].

3) Invest in Training on Disruptive Technologies. Every member of the internal audit in the organization must continually upgrading their knowledge in technology related issue. Giving the proper training in technology can enhance the competencies of internal audit staff which makes them more valuable talent to organization [30].

Put New Technologies to Work. New challenge requires new methods. Therefore, change should be made in the way of internal audit process conducted. Internal audit should consider the use of new technologies, such as big data and algorythim, for example, to provide real time and comprehensive internal audit result [30].

\section{RESEARCH METHOD}

Research is conducted using a single case study design. The method used is the field study. Field studies were conducted at the Internal Audit Unit or SPI at University X by conducting interviews with the staff and collecting data, such as the University X Annual Work Plan 2015-2017, University X Strategic Plan 2015-2018, AUN-QA Self Assessment Report 2016, Internal Control Unit (SPI) report for the first half of 2017, and University X statistics for 2012-2016.

The analysis had three steps. First, the authors gathered secondary data, such as the HE risk profile, University $\mathrm{X}$ statistics for 2012-2016, and the AUN-QA Self Assessment Report 2016. Second, the authors engaged in observations for three months at the SPI of University X. During the observations, the authors conducted interviews with SPI staff 
to gather information on how SPI identifies, analyzes, and assesses University X's risks. Third, the authors analyzed whether the current internal audit practice and internal audit work plan made by University X's SPI are in accordance with the statistics, trends, and assessment reports, and other IIA best practices. The aim of this method is to evaluate whether the 2017 internal audit work plan created by SPI University X was already tailored to the trends and current needs of $\mathrm{HE}$ in the disruptive era of technology.

\section{RESUlt AND DisCUSSION}

\section{A. Current Practices}

When conducting their RBIA approach, SPI University X mainly focuses on operational risk, financial risk, and compliance risk, among other risks, because those risks must be addressed first to ensure that effective internal controls throughout the organization can be achieved. IIA suggested that, when carrying out the RBIA, the scope of the risk being managed must not only focus on operational risk, financial risk, and compliance risk but also primarily on strategic risk.

SPI University $\mathrm{X}$ divided the risks into six major categories: information system risk; project risk; activity risk; infrastructure risk; entity risk; organs in the Center of Administration risk; and organs in the faculty and study program risk. SPI University $\mathrm{X}$ prioritized this risk by multiplying the impact and likelihood scores that were already aligned with the IIA RBIA methodology. When determining the audit universe, the SPI uses data and audit reports of University X. From the audit reports, SPI then identifies risk and creates the audit universe. The completion of the University $\mathrm{X}$ audit findings then becomes the main focus of the implementation of the RBIA by SPI University $\mathrm{X}$. Examples of the audit universe and risk categories identified by SPI University $\mathrm{X}$ are as follows (Table I).

\section{B. Suggested Practice}

The authors then attempted to suggest risks based on many sources and best practices conducted by other universities around the world. The approach that the authors used to determine risk factors for University X is quite different from the SPI University X approach. The authors use the specific risk approach, in which the risks already specified in every auditable unit and that are not too generic are emphasized. The specific risk approach is aimed to achieve the organization's main objective-University X's objective - of having an excellent university reputation. The authors then categorized the risks into an audit universe, such as noted in Table II.

Among these risks, the authors focus on four of the top risks: teaching and learning process, human resources, information technology, and graduate student development. These risks are explained in Table III.

Based on the authors' analysis, University X's key risk is in the teaching and learning process. Statistics published by University $X$ in 2017 showed that the number of online courses provided a total of 14 faculties and three study programs, but there were only six in 2016. This number increased slightly from 2014, when only four courses were provided, but is quite worrisome considering that, today, millennial students prefer university to online sources of learning. Both students from within the campus and external parties want to access the learning materials given by every University $\mathrm{X}$ faculty and study programs. University $\mathrm{X}$ actually already has a website called University X Online Course Ware (UXOCW), which provides learning materials that, although quite limited, can be accessed by outside parties. In some faculties, the use of SCeLE has been encouraged by lecturers, but it is not applied equally by other faculties. Other faculties also have attempted to integrate the use of technology such as PowerPoint and video conference learning. However, according to the statistics provided by University X, only three among 14 faculties in 2016 had already applied this type of learning activity. The number of study programs that provide e-learning materials increased significantly from 2015 to 2016, with 2016 having 161 study programs among 14 faculties and three study programs with e-learning activities. Again, these types of programs are not applied equally by other faculties.

TABLE 1. EXAMPLE OF RISK CATEGORIES AND AUDIT UNIVERSE BY SPI UNIVERSITY X (2017)

\begin{tabular}{|l|l|}
\hline Audit Universe Category & \multicolumn{1}{|c|}{ Risk Mapping Area } \\
\hline Information System Risk & $\begin{array}{l}\text { University X's Connectivity (Djuita) } \\
\text { Oracle System } \\
\text { SIMAK BMN/SIMAF } \\
\text { SIAK-NG }\end{array}$ \\
\hline Project Risk & $\begin{array}{l}\text { Asset grant } \\
\text { Construction engagement } \\
\text { Agreement with third parties }\end{array}$ \\
\hline Activity Risk & $\begin{array}{l}\text { Recruitment of staff and lecturers } \\
\text { Student admission } \\
\text { Budgeting: preparation and realization of } \\
\text { the budget } \\
\text { IT integration } \\
\text { Procurement process } \\
\text { Asset inventory }\end{array}$ \\
\hline Infrastructure Risk & $\begin{array}{l}\text { Parking lot } \\
\text { University X library } \\
\text { University X laboratory } \\
\text { University X waste management } \\
\text { University X Hospital }\end{array}$ \\
\hline $\begin{array}{l}\text { Entity Risk: Center of } \\
\text { Administration Risk }\end{array}$ & $\begin{array}{l}\text { All directorates in the Center of } \\
\text { Administration University X }\end{array}$ \\
\hline Raculty and Study Program & $\begin{array}{l}\text { All faculties, study program, and school } \\
\text { in University X }\end{array}$ \\
\hline
\end{tabular}

TABLE II. AUDIT UNIVERSE CATEGORIES

\begin{tabular}{|l|l|}
\hline \multicolumn{1}{|c|}{ Audit Universe Category } & Description \\
\hline $\begin{array}{l}\text { Teaching and learning process } \\
\text { risk }\end{array}$ & Risks related to the organization of academic activities within the scope of the institution. \\
\hline Student admission risk & Risks associated with registration and admission of new students. \\
\hline Administrative risk & Risks associated with administrative services at the institutional level. \\
\hline
\end{tabular}




\begin{tabular}{|l|l|}
\hline Contract risk & $\begin{array}{l}\text { Risks arising out of a cooperation agreement with a third party (vendors, suppliers, and other external parties assisting } \\
\text { in the operational process at UX). }\end{array}$ \\
\hline Infrastructure risk & Risks related to facility management of fixed assets at the institution. \\
\hline Financial risk & $\begin{array}{l}\text { Risks arising from inadequate financial management, inadequate monitoring of financial statements, and exposure of } \\
\text { investment activities undertaken by UX. }\end{array}$ \\
\hline Human resource risk & Risks related to the management of human resources, such as UX personnel, employees, lecturers, and other staff. \\
\hline Information technology risk & Risks arising from lack of information systems procedures and policies in the use of technology. \\
\hline Public safety risk & Risks relating to the public security of those within the UX. \\
\hline $\begin{array}{l}\text { Research, development, and } \\
\text { community service risk, }\end{array}$ & Risks relating to research and innovation activities undertaken by UX civitas. \\
\hline Student life risk & Risks relating to the physical and mental well-being of students who perform academic activities in the UX environment. \\
\hline $\begin{array}{l}\text { Graduate student development } \\
\text { risk }\end{array}$ & Risks associated with the development of students, since from the orientation process until they graduate from UX. \\
\hline Legal risk & Risks arising from non-compliance with laws and regulations relating to the conduct of higher education. \\
\hline Reputation risk & Risks relating to the good reputation and reputation of the University X, both domestically and abroad. \\
\hline
\end{tabular}

TABLE III. AUdit UNIVERSE CATEGORIES

\begin{tabular}{|l|l|l|l|}
\hline No. & \multicolumn{1}{|c|}{$\begin{array}{c}\text { Audit Universe } \\
\text { Categories }\end{array}$} & \multicolumn{1}{c|}{$\begin{array}{c}\text { Risk Related to Audit } \\
\text { Universe }\end{array}$} & Risk Description \\
\hline 1. & $\begin{array}{l}\text { Teaching and learning } \\
\text { process risk }\end{array}$ & $\begin{array}{l}\text { Insufficiency of online learning } \\
\text { source and distant learning } \\
\text { materials }\end{array}$ & $\begin{array}{l}\text { Online or distant learning materials from UX OCW (Open Course Ware) that can } \\
\text { be acessed through the online system by students or outside parties is not } \\
\text { complete and is insufficient in number given infrequent updates by faculty } \\
\text { members or the campus. In an era of disruptive technology, the need for } \\
\text { personalized learning materials that can be accessed anywhere and by anyone is } \\
\text { increasing. }\end{array}$ \\
\hline 2. & $\begin{array}{l}\text { Teaching and learning } \\
\text { process risk }\end{array}$ & $\begin{array}{l}\text { Courses that have already been } \\
\text { tailored to the needs of the } \\
\text { present world are insufficient }\end{array}$ & $\begin{array}{l}\text { Courses provided by the university are not or have not been able to respond to } \\
\text { the needs of the present environment. }\end{array}$ \\
\hline 3. & $\begin{array}{l}\text { Human resource risk } \\
\text { Teachers and staff who do not } \\
\text { meet expected qualifications }\end{array}$ & $\begin{array}{l}\text { Positions have been filled by unqualified staff because of the lack of qualified } \\
\text { personnel. }\end{array}$ \\
\hline 4. & $\begin{array}{l}\text { Information } \\
\text { technology risk }\end{array}$ & $\begin{array}{l}\text { Inability to develop and integrate } \\
\text { IT resources and data centers into } \\
\text { teaching and learning processes }\end{array}$ & $\begin{array}{l}\text { IT system is not yet integrated equally throughout the faculty and other organs } \\
\text { within the campus. }\end{array}$ \\
\hline 5. & $\begin{array}{l}\text { Graduate } \\
\text { development risk }\end{array}$ & $\begin{array}{l}\text { Less competitive graduates } \\
\text { compared with those from other } \\
\text { universities throughout the world }\end{array}$ & $\begin{array}{l}\text { Graduates are less competitive than other graduates both within and outside the } \\
\text { country, especially in the technology sector, given a lack of digital literacy and } \\
\text { special programs provided by the campus. }\end{array}$ \\
\hline
\end{tabular}

The second major risk is the technology capability among educators and the staff. According to University X statistics, only 23 out of the 2,521 lecturers at University X had already joined the Information and Communication Technology Training in 2016. This statistic is quite worrisome. As we know, HE institutions today must encourage innovation from their students through lecturers who have proper digital literacy. If their lecturers do not have the awareness to increase their knowledge of technology and change the way they teach, then students that graduate from University X could be less competitive than those from other WCUs that have already attempted to be more innovative and have lecturers who have adjusted their ways of teaching and learning to benefit their students.

The third and final risks are information technology risk and graduate student development risk. Today, technology plays an important role in conducting teaching and learning activities. All graduates in this $21^{\text {st }}$ century are expected to have strong academic, interpersonal, and intrapersonal skills. To develop a competitive graduate, University $\mathrm{X}$ needs to carefully analyze each student's performance. By using technology such as learning analytics, University $\mathrm{X}$ will be able to understand and optimize their students' potential and provide real-time feedback to their learning progress. Therefore, the use of applications, mobile learning, and learning management systems at University $\mathrm{X}$ should be considered.

\section{CONCLUSION AND IMPLICATION}

Following any given success, the disruptive technology era that resulted from industrial revolution 4.0 creates new problems and risks. The era of intense competition between organizations can lead to obsolescence and may even end up in extinction in a relatively shorter period. This situation will cause every HE institution to pay more attention to achieving and maintaining their reputable names and to evolving to adapt in this rapidly changing environment. As the authors previously mentioned, HE institutions now compete in an era full of uncertainty in which reputable names cannot always guarantee their own survival. In the era of disruptive technology, student preferences are also changing slightly. Universities need to pay more attention to the use and integration of technology to fulfill their student needs, and lecturers must enhance their digital literacy.

SPI University $\mathrm{X}$ as a catalyst of change has not yet linked its risks to its overall organizational objectives because its main focus is still on three risks: operational, financial, and compliance risks. The main scope that has become the primary focus of the implementation of an SPI internal audit is mostly a non-academic audit activity. Additionally, SPI has not yet focused on the technology risks cause by the disruptive innovation era. Therefore, the authors' analyses concluded that some risks should be prioritized given rapid changes in 
technology. Moreover, technology risks should be viewed as strategic risks that, if neglected, could potentially cause University X's reputation to be weakened considering that every other university is now becoming more competitive than ever. A reputable name in itself cannot guarantee that a university can survive industrial revolution 4.0 .

Nevertheless, SPI does not neglect the importance of this risk. Overall, SPI has attempted to link its risk universe with organizational objectives to fit University X's needs. However, greater effort needs to be made to become the organization's catalyst for change. As we know, the entire environment is now changing rapidly because of the disruptive technology era. In other words, SPI should put more attention on identifying, assessing, and managing the risks that resulted from technology disruptions. The most vocal point to implementing a RBIA is to add value to the organization, which can be done if the three major risks (operational, financial, and compliance) are properly resolved. Therefore, in the future, SPI should focus on not only operational, financial, and compliance risks.

\section{RECOMMENDATIONS}

Suggestions given to SPI University $\mathrm{X}$, as well as University $\mathrm{X}$, are as follows.

Suggestions to be provided to SPI University $\mathrm{X}$ are as follows.

1) SPI University $X$ should begin to consider risks beyond financial, operational, and compliance risks and focus on strategic risks that may affect the University's reputation. In this case, the strategic issue occurring globally is technology disruption. SPI University $\mathrm{X}$ as a catalyst for change should be able to guarantee the position and good reputation possessed by University $\mathrm{X}$ amidst the increasing competition among universities with respect to innovating and adapting to technological change.

2) Completing and adjusting the existing audit universe every year is necessary because changes in the organization's environment affect the existing audit universe.

Suggestions that authors could offer to University $\mathrm{X}$ are as follows. University $\mathrm{X}$ has already developed a good reputation and is acknowledged not only in Indonesia but also throughout the world, according to the QS WU ranking. However, a good reputation is not enough for University $\mathrm{X}$ to stand against the current. Therefore, the following suggestions are made to University $\mathrm{X}$ based on the results of the analyses and the best practices carried out by NMC Horizon Report 2017 [32].

3) Deeper Learning Approaches. A deeper learning approach means that University $\mathrm{X}$ must focus on giving its students material or content that stimulates their critical thinking, problem solving, collaboration, and self-directed learning. The outcome of a deeper learning approach for students is that they must know how to apply their knowledge from the coursework to real-world needs and the impact of new knowledge and skills on their near futures.

4) Focus on Learning Measurement Tools. University X should focus on measuring the learning progress of each student. In the current practice, University X only records its students grades and marks. However, the trend in $\mathrm{HE}$ is that universities today are moving forward with not only recording grades but also measuring, evaluating, and documenting their students' learning progress, skills acquisition, and soft skills, such as creativity and collaboration. This effort is made through the use of online education, mobile learning, and learning management systems. By using software, data from these tools can be extracted and analyzed to provide University $\mathrm{X}$ with information on their students' performance.

5) Focus on Ed Tech. Classrooms should be provided with multiple devices and tools that support active learning and project-based learning experiences for students. University X can start by developing its infrastructure, such as wireless bandwidth, to support stable connections throughout the campus environment, enabling students to gain access to the Internet not only inside their classrooms. Furthermore, University X can integrate its education system with current technologies, such as 3D or holographics, to provide students with organic interactions. This adoption of technology into the teaching and learning experience is called Ed Tech, which is expected to replace the traditional classroom teaching and learning processes.

6) Blended Learning and Collaborative Learning. Blended learning focuses on the ease of access and flexibility in the teaching and learning process through online learning. Collaborative learning means that students and educators work together in group activities. With the help of technology, such as online learning portals, applications, cloud-based services, and other apps, students and educators can easily exchange knowledge and information and engage in remote communication.

Technology may undergo a revolution, but humans remain social creatures that require interactions with one another. Thus, a profession that maintains an interactive relationship with ethical equality, as is the case in an adaptive university, will continue to exist.

\section{ACKNOWLEDGMENT}

I would like to express my deep and sincere gratitude to Robert Porhas Tobing as my research mentor, for giving me the wonderful opportunity to complete my undergraduate thesis under his supervision, it is truly an honor. His vision, sincerity, and motivation have deeply inspired me. Thank you for all the advice, ideas, and patience in guiding me through this project. Your wealth of knowledge in the field of auditing and intermal audit in particular is inspiring. Thank you for giving me the opportunity to grow in this field of research.

I am extending my gratitude to every personel in Satuan Pengawas Internal (Internal Audit Unit), University of Indonesia for their support during my research work. I thank Tanty Verawati Reyne, Susiana Liu, Raisiffah Kunti, and everyone else for their genuine support throughout this research work.

Finally, my thanks go to all the people who have supported me to complete the research work directly or indirectly.

\section{REFERENCES}

[1] Moreira, F., \& Rocha, Á. (2018). A Special Issue on Disruption of higher education in the 21 st century due to ICTs. 930-932

[2] Disrupting Internal Audit Functions in the TMT Sector (KPMG, January 2017) Retrieved from https://assets.kpmg/content/dam/kpmg/ 
cn/pdf/en/2017/01/disrupting-internal-audit-risk-managmentfunctions-in-tmt.pdf

[3] Schuelke-Leech, B. A. (2018). A model for understanding the orders of magnitude of disruptive technologies. Technological Forecasting and Social Change, 129, 261-274

[4] Bower, J. L., \& Christensen, C. M. (1995). Disruptive technologies: Catching the wave

[5] Christensen, C. M., \& Eyring, H. J. (2011). The innovative university: Changing the DNA of higher education from the inside out. John Wiley \& Sons.

[6] Pincus, K. V., Stout, D. E., Sorensen, J. E., Stocks, K. D., \& Lawson, R. A. (2017). Forces for change in higher education and implications for the accounting academy. Journal of Accounting Education, 40, 118 .

[7] The 2015 Campus Computing Survey (The Campus Campus Computing Project (October 29, 2015) Retrieved from https://www.campuscomputing.net/content/2015/10/29/the-2015campus-computing-survey

[8] Bradshaw, J. (2014). Ontario to launch \$42-million central hub for online postsecondary classes. The Globe and Mail.

[9] Canadian Council on Learning. (2009). The state of e-learning in Canada. Canadian Council on Learning.

[10] Sawyer, L. B. (2012). Sawyer's Guide for Internal Auditors Vol. 2 Internal Audit Essentials, 6th Edition. Florida: The Institute of Internal Auditors Research Foundation (IIARF)

[11] Goodwin, J. (2004). A comparison of internal audit in the private and public sectors. Managerial Auditing Journal, 19(5), 640-650.

[12] Getie Mihret, D., \& Wondim Yismaw, A. (2007). Internal audit effectiveness: An Ethiopian public sector case study. Managerial Auditing Journal, 22(5), 470-484

[13] De Zwaan, L., Stewart, J., \& Subramaniam, N. (2011). Internal audit involvement in enterprise risk management. Managerial auditing journal, 26(7), 586-604.

[14] Achua, J. K., \& Alabar, T. T. (2014). Imperatives of marketing internal auditing in Nigerian universities. Procedia-Social and Behavioral Sciences, 164, 32-40

[15] Abdolmohammadi, M. J., DeSimone, S. M., Hsieh, T. S., \& Wang, Z. (2017). Factors associated with internal audit function involvement with XBRL implementation in public companies: An international study. International Journal of Accounting Information Systems, 25, 45-56

[16] Pickett, K. H. S. (2010). The Internal Auditing Handbook, Chichester, West Sussex, United Kingdom: Wiley

[17] Lemon, W. M. \& Tatum, K.W. (2003). "Internal auditing systematic and disciplined process," in Bailey, A.D., Gramling, A.A. and Ramamoorti, S. (Eds), Research Opportunities in Internal Auditing,
The Institute of Internal Auditors Research Foundation, Altamonte Springs, FL, 269-301

[18] KPMG (2007), The Evolving role of Internal Auditor - Value Creation and Preservation from an Internal Audit Perspective, KPMG LLP

[19] Caratas, M. A., \& Spatariu, E. C. (2014). Contemporary approaches in internal audit. Procedia Economics and Finance, 15, 530-537

[20] Coetzee, P., \& Lubbe, D. (2014). Improving the efficiency and effectiveness of risk-based internal audit engagements. International Journal of Auditing, 18(2), 115-125.

[21] Effendi, Muh. Arief. (2006). Perkembangan Profesi Internal Audit Abad 21. Batam: Universitas Internasional Batam

[22] McDonad, C. (2016). Internal audit roles expanding further into risk areas. Available from: http://www.riskmanagementmonitor.com/ audit-role-expanding-further-into-risk-areas/ [Accessed 24 July 2017]

[23] Selim, G., \& McNamee, D. (1999). Risk management and internal auditing: What are the essential building blocks for a successful paradigm change? International Journal of Auditing, 3(2), 147-155.

[24] Coetzee, P. and Lubbe, D. (2014), "Improving the efficiency and effectiveness of risk-based internal audit engagements", International Journal of Auditing, Vol. 18 No. 2, pp. 115-125

[25] Risk Based Internal Auditing (Institute of Internal Auditor, October 8, 2014) Retreieved from https://global.theiia.org/standardsguidance/topics/Documents/201501GuidetoRBIA.pdf

[26] Ahlawat, S. S., \& Lowe, D. J. (2004). An examination of internal auditor objectivity: in-house versus outsourcing. Auditing: A Journal of Practice \& Theory, 23(2), 14-158.

[27] Brody, R. G., \& Lowe, D. J. (2000). The new role of the internal auditor: Implications for internal auditor objectivity. International Journal of Auditing, 4(2), 169-176.

[28] Plumlee, R. D. (1985). The standard of objectivity for internal auditors: memory and bias effects. Journal of Accounting Research, 23(2), 683699.

[29] The Institute of internal Auditors. (2009b). IIA position paper: The role of internal auditing in enterprise-wide risk management. London: IIAUK.

[30] Global perspective and insights: Internal audit in the age of disruption (Institute of Internal Auditor, 2018) Retrieved from https://na.theiia.org/periodicals/Public\%20Documents/GPI-InternalAudit-in-the-Age-of-Disruption.pdf

[31] 2017 State of the Internal Audit Profession Study (PwC, March 2017), Retrieved from https://www.pwc.ru/ru/publications/ internalauditstudy/State-of-the-InternalAudit\%20Profession 2017.pdf

[32] Becker, S. A., Cummins, M., Davis, A., Freeman, A., Hall, C. G., \& Ananthanarayanan, V. (2017). NMC horizon report: 2017 higher education edition (pp. 1-60). The New Media Consortium 